С.О. Кадук, А.С. Сторожук, С.Ю. Стрельчик, Р.А. Сікорський

Харківський національний університет Повітряних Сил ім. І. Кожедуба, Харків

\title{
ВИКОРИСТАННЯ ІНФОРМАЦІЇ РАДІОЛОКАЦІЙНОЇ РОЗВІДКИ АDS-В ПРИ СТВОРЕННІ ЄДИНОГО ІНФОРМАЦІЙНОГО ПРОСТОРУ ПОВІТРЯНИХ СИЛ ЗБРОЙНИХ СИЛ УКРАЇНИ
}

Сучасні інформачійні технології дозволяють створювати інформачійний простір шляхом об’єднання різноманітної інформаџії від різнорідних джерел. В статті розглядається спосіб об’єднання радіолокаційної інформації від радіолокаційних станцій Повітряних Сил та приймачів ADS-B. Показано, щсо за рахунок використання ADS-B даних можна суттєво розширити радіолокаційний простір та отримати додаткову інформацію для попередження будь-яких порушень у повітряному просторі Украӥни.

Ключові слова: радіолокаційний контроль, порушення повітряного простору, оцінка повітряної обстановки, MLAT, ADS-B.

\section{Вступ}

Постановка проблеми. За останні десятиліття інтенсивність повітряного руху зросла у декілька разів. На даний момент в зоні відповідальності пунктів управління авіації Повітряних Сил Збройних Сил України (далі - ПС ЗСУ) знаходиться велика кількість повітряних об'єктів (далі - ПО) як військового так i цивільного призначення, що безумовно, ускладнює виконання завдань 3 ведення якісного та ефективного радіолокаційного контролю (РЛК), відслідковуванню та запобіганню будь-яких порушень у повітряному просторі України.

Аналіз останніх досліджень і публікацій. На даний час існує значний обсяг літератури 3 технічним описом режиму “S” системи вторинної локації RBS та системи ADS-B. Найбільш точний опис наводиться в офіційних документах міжнародної організації цивільної авіації (ICAO) [12]. В той же час дослідження стосовно використання цих систем в інтересах радіотехнічних військ ПС ЗСУ практично не проводилися.

Вимоги Євроконтролю до системи РЛ спостереження. Згідно 3 [3-4] радіолокаційне спостереження має забезпечувати в усьому європейському повітряному просторі горизонтальне розрізнення повітряних суден не гірше 5 морських миль на маршрутах (En-Route Airspace) 3 високою щільністю суден, 10 миль в іншому просторі маршрутів і 3 милі в головних районах аеродромів (Major Terminal Area).

Покриття радіолокаційним полем (далі - РЛП) має бути таким:

- на маршрутах - подвійне перекриття поля вторинної радіолокації (далі - ВРЛ);
- в районах аеродромів - однократне поле первинної радіолокації (далі - ПРЛ) і подвійне перекриття поля ВРЛ.

У просторі маршрутів подвійне радіолокаційне поле ВРЛ має простиратись не менше ніж на 30 морських миль за межі відповідальності центру контролю i охоплювати по висоті простір від нижчого FL20 (600 м) до вищого FL510 (15100 м для України) рівню польоту за правилами польотів по приладах (IFR - Instrument Flight Rules).

У [3] відсутні указівки на використання військових РЛС або РЛС подвійного призначення, але відмічається, що вказані принципи побудови системи радіолокаційного спостереження можуть бути застосовані на національному рівні для сумісного використання військових та цивільних РЛС.

Система радіолокаційного спостереження має надавати таку інформацію про повітряні судна:

- поточні площинні координати та передісторія pyxy;

- дані впізнавання (у режимі А або S ВРЛ); положення у вертикальній площині;

- наявність аварійних кодів у відповіді (7500, 7600, 7700);

- швидкість відносно поверхні Землі;

- статус траси (від первинної РЛС, від вторинної РЛС, комбінована або екстрапольовані дані).

Середньоквадратичне відхилення (далі - СКВ) місцеположення судна за даними радіолокаційного спостереження має бути, не більше: на маршрутах 500 м; в районах аеродромів - 300 м.

Темп поновлення даних спостереження має бути, не більше: на маршрутах -8 с; в районах аеродромів $-5 \mathrm{c}$. 
Припустимим $є$ оновлення даних про місцеположення судна за даними екстраполяції не більше ніж 2 оновлення підряд.

Дані про висоту режиму C не можуть бути екстрапольовані.

Виконання вимог до даних спостереження має бути забезпеченим побудовою інфраструктури системи і може бути досягнуте: використанням РЛС 3 високими тактико-технічними характеристиками (далі - TTX); комбінуванням інформації первинних і вторинних каналів РЛС; комбінування інформації різних РЛС, у тому числі аеродромних і трасових; мультирадарним супроводженням з високими ТТХ.

Надійність забезпечення даними радіолокаційного спостереження має бути, не менше: основних даних спостереження 0,99999; повних даних спостереження 0,995 (за виключенням періоду планового обслуговування); даних первинних РЛС в районах аеродромів 0,995.

Повні дані спостереження включають:

- площинні координати та передісторію руху;

- дані впізнавання;

- положення у вертикальній площині;

- наявність аварійних кодів у відповіді;

- швидкість відносно поверхні Землі;

- статус траси.

Основні дані спостереження включають:

- площинні координати та передісторію руху;

- дані впізнавання або код режиму А;

- положення у вертикальній площині.

Виконання вимог до надійності забезпечення даними спостереження має бути забезпечено побудовою інфраструктури системи і може бути досягнуте:

- дублюванням РЛС;

- автоматичним перемиканням на автономну (резервну) РЛС;

- вводом додаткових РЛС;

- резервними засобами;

- радіолокаційними каналами прямого доступу;

- використанням даних обробки інформації від інших джерел (наприклад, центрального сервера).

Архітектура системи має гарантувати, що відмова одного елемента мережі РЛС не знизить суттєво можливості системи керування повітряним рухом.

Аналізуючи керівні документи Міністерства оборони України, в яких могли би бути задані вимоги до джерел радіолокаційної інформації, системи радіолокаційної розвідки, показав, що у цих документах відсутні прямі вимоги до характеристик радіолокаційних засобів.

У документах відсунуті також й узагальнені вимоги до позицій засобів радіолокації пунктів управління авіації ПС ЗСУ.
Вимоги до засобів радіолокації формувалися окремими тактико-технічними завданнями (далі ТT3) при їх розробці, виходячи із завдань системи розвідки повітряного противника або систем, які вони забезпечують. Тому доцільно, за відсутністю єдиних вимог, аналізувати наявні тактико-технічні характеристики РЛС ПУА ПС ЗСУ.

Мета статті. Аналіз можливостей використання інформації ADS-B для підвищення ефективності проведення РЛК повітряного простору України.

\section{Виклад основного матеріалу}

Розпізнавання ситуачій порушення повітряного простору України. Одним з основних завдань чергової бойової обслуги з протиповітряної оборони, відповідно до існуючих нормативних документів $€$ припинення порушень порядку використання повітряного простору України, протиправних дій повітряних суден, якщо вони використовуються з метою здійснення терористичного акту, дії при виявленні (розкритті) масового зльоту i польоту ЗПН у напрямку державного кордону України.

Безпосередньо завдання щодо припинення порушень повітряного простору України покладено на пункти управління авіацією ПС ЗСУ.

Командири винищувальних авіаційних бригад через командні пункти приймають рішення та здійснюють управління по припиненню порушень повітряного простору України, а також перехоплення повітряних суден порушників повітряного простору України в межах радіолокаційної видимості своїх засобів.

У складі будь-якого рішення по оцінці повітряної обстановки лежить збір, обробка й аналіз інформації, що ії характеризують. Процес прийняття рішення при управлінні складними об'єктами і системами нерозривно пов'язаний 3 вирішенням задачі розпізнавання ситуацій, що складаються у повітряному просторі.

Згідно керівних документів 3 контролю повітряного простору України та порядку його використання повітряними судами слід відокремити дві основні ситуації, що виникають в повітряному простоpi - “штатну” та “позаштатну.

“Штатна” ситуація передбачає рух повітряного судна в заданому коридорі прольоту, з заданою швидкістю, та висотою, курсом руху, в заданому проміжку часу, у відповідності з розкладом (заявою) на політ та кількістю вказаними у заявці.

Під “позаштатною” ситуацією мається на увазі рух повітряного судна 3 порушенням деяких параметрів “штатної” ситуаціі”. 


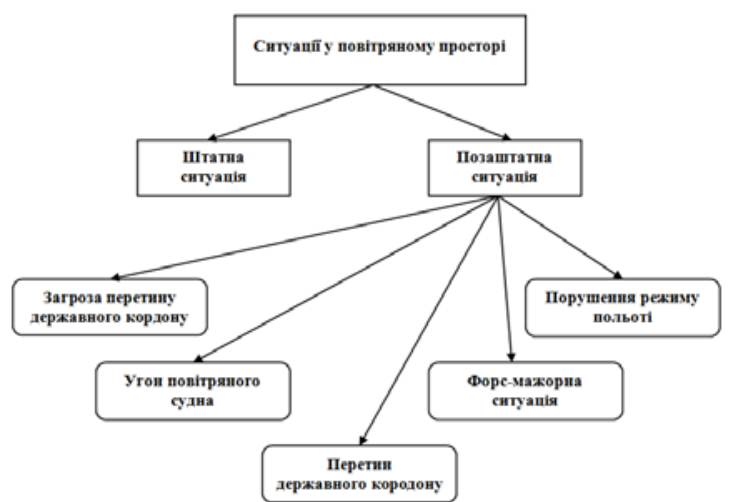

Рис. 1. Ситуації, що виникають в повітряному просторі

Джерело: [11, С. 32].

Слід зазначити, що “позаштатна” ситуація може містити ряд різновидів порушень правил використання повітряного простору.

Для процесу визначення ознак порушення повітряного простору необхідно проаналізувати сукупність інформаційних ознак. Ці дані можна розділити на дві групи:

1. Дані, що надходять від радіолокаційної розвідки. Такі дані характеризуються мінімальною затримкою за часом, оскільки формуються за результатами кожного огляду повітряного простору радіолокаційними засобами.

До таких даних належать: плоскістні координати повітряного об'єктуна даний момент часу; висота польоту повітряного об'єкту; швидкість руху повітряного об'єкту; курс руху повітряного об'єкту; час прольоту; номер заяви на політ; кількість повітряних об'єктів; наявність чи відсутність сигналу лиха; ознака державної належності; наявність чи відсутність несприятливої метеообстановки; наявність чи відсутність несприятливої орнітологічної обстановки;

2. Дані диспетчерського контролю: заданий ешелон висоти; задана швидкість польоту; заданий курс польоту; заданий інтервал часу польоту повітряного судна; запланований номер повітряного судна; кількість повітряних об'єктів указаних в заяві на політ.

Відомо [1-4], що в теперішній час основними засобами ведення радіолокаційного контролю (РЛК) є радіолокаційні станції (РЛС).

Поряд 3 активними первинними РЛС в цивільній авіації для контролю повітряного простору вже досить тривалий час використовують технологію системи (MLAT). В якості приймачів в системі MLAT використовуються приймачі ADS-B.

Використання приймачів ADS-B дає можливість супроводження повітряних об'єктів в режимі реального часу. Це наглядно можна простежити 3 використанням інтернет ресурсу FlightRadar24.
Враховуючи технічні характеристики приймачів ADS-B, $\epsilon$ можливість отримання додаткової інформації про ПО та підвищення точності їх супроводу [5].

А враховуючи максимальну дальність дії, що складає приблизно 400 км, можна отримувати дані від ПО, що не входять у повітряний простір України i відповідно про які нема відомостей у органах управління повітряним рухом України. Тобто 3'являється можливість отримувати дані про ПО, що здійснюють польоти вздовж кордону України, не перетинаючи його.

Однак для забезпечення отримання якомога точних координат ПО, що не входять у повітряний простір України, використовуючи технологію MLAT, необхідно забезпечити оптимальне геометричне розміщення ADS-B приймачів системи (рис. 2).

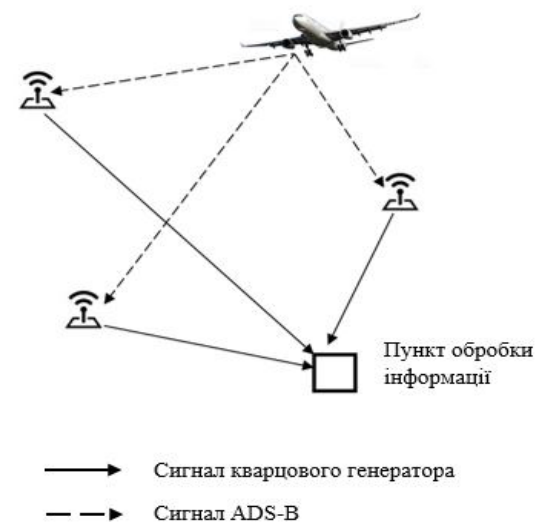

Рис. 2. Схема розміщення системи приймачів ADS-B

Джерело: [5, С. 69].

Крім того приймачі повинні розташовуватися на достатньо великій відстані один від одного, в іншому випадку точність визначення координат ПО на великій відстані може бути визначена 3 великою похибкою (рис. 3).

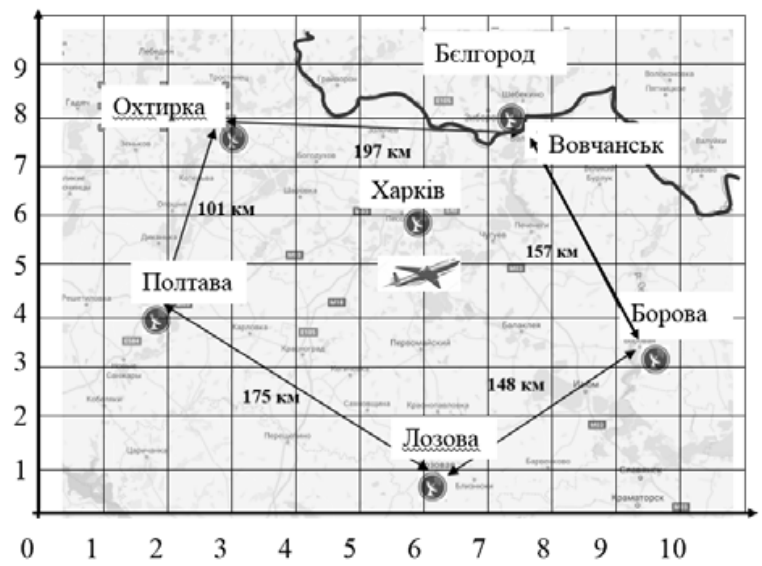

Рис. 3. Розміщення приймачів ADS-B на прикладі розташування аеропортів України поблизу кордону 3 Російською федерацією (далі - РФ) Джерело: [5, С. 75]. 
Таким чином, використовуючи принцип технології MLAT можна розмістити по одному приймачу ADS-B на позиціях окремих ПУА ПС ЗСУ, що значно зробить ефективнішою роботу чергової бойової обслуги пункту управління.

Інформачійні можливості системи $A D S-B$. Фактично ADS-B є елементом режиму “S” системи вторинної оглядової радіолокації для управління повітряним рухом RBS (Radar Beacon System) [6].

Автоматичне залежне спостереження - радіомовне (ADS-B) - це технологія коопераційного спостереження, в якій ПС визначає своє місцеположення через супутникову систему навігації та поширює його бортовим відповідачем. Цю інформацію можуть отримувати як наземні станції підрозділів управління повітряним рухом (далі - УПР), так і інші повітряні судна, що дає змогу екіпажам бути більш ситуаційно обізнаними.

ADS-B - “автоматичне” - тому, що діє без втручання екіпажу. “Залежне” - тому, що залежить від даних навігаційних систем повітряного судна.

Технологія ADS-B, яка складається 3 двох різних сервісів, “ADS-B Out” та “ADS-B In”, цілком може замінити радіолокатор, як основний засіб спостереження за повітряним рухом. “ADS-B Out” через бортовий передавач поширює інформацію про точне місцеположення, висоту та швидкість повітряного судна (далі - ПС), а також інші дані $з$ бортових систем ПС. “ADS-B In” приймає інформацію 3 каналів FIS-B (Польотноінформаційного сервісу ) та TIS-B (Інформацію про інший рух), а також інші данні ADS-B, такі як пряме спілкування з ПС, які перебувають поблизу.

B ADS-B передається великий обсяг даних (табл. 1), але для вирішення завдання розвідки повітряного простору представляють інтерес наступні: координати ПС в системі координат WGS84 (передаються 2 рази за секунду); значення висоти ПС, швидкості та курсу; значення вертикальної швидкості; код режиму “А” системи RBS (так званий SQUAWK); адреса ICAO ПС (передається в кожному повідомленні); позивний (Callsign) ПС.

Таблиця 1

Дані, що входять до складу ADS-B повідомлення

\begin{tabular}{|c|c|c|}
\hline $\begin{array}{c}\text { Тип } \\
\text { повідомлення } \\
\end{array}$ & $\begin{array}{c}\text { Сквіт } \\
\text { тер }\end{array}$ & Інформація \\
\hline \multirow{4}{*}{$\begin{array}{l}\text { ADS-B } \\
\text { (56 bits) }\end{array}$} & DF4 & інформація про висоту \\
\hline & DF5 & інформація про SQUAWK \\
\hline & DF11 & $\begin{array}{l}\text { інформація про адресу } \\
\text { ІСАО }\end{array}$ \\
\hline & DF20 & інформація про позивний \\
\hline $\begin{array}{l}\text { ADS-B } \\
\text { (112 bits) }\end{array}$ & DF17 & $\begin{array}{l}\text { координати ПО в системі } \\
\text { координат WGS-84; } \\
\text { значення вертикальної } \\
\text { швндкості; } \\
\text { тип ПО; } \\
\text { швидкість ПО. }\end{array}$ \\
\hline
\end{tabular}

Джерело: [5, С. 70].
Перелічені дані випромінюються 3 різною дискретністю від 0.5 секунди до 10 секунд.

Координати ПС в системі WGS-84 визначаються бортовими GPS навігаторами, тобто мають суттєво вищу точність, ніж дані 3 радіолокаційних засобів. Дискретність передачі координатних даних (2 рази в секунду) також суттєво менше дискретності даних від радіолокаційних засобів. Значення швидкості та курсу в більшості випадків також беруться 3 бортових GPS навігаторів, але можуть братись 3 іншого бортового обладнання. В більшості випадків значення висоти береться 3 барометричного висотоміру ПС.

Адреса ICAO повітряного судна - це шости розрядний 16-річний код, що надається ПС на весь час його існування для використання його в режимі “S” системи управляння повітряним рухом RBS. Тобто, за цими кодами може бути утворена база даних, по якій може бути виявлено конкретне повітряне судно. Наприклад, єдиний у світі літак Ан-225 “Мрія" має адресу ICAO 508035 та $є$ власністю КБ Антонова. Реєстраційний номер літака UR-82060. Тобто за допомогою такої бази даних може бути встановлене:

- тип повітряного судна;

- номер реєстрації (наноситься на фюзеляж та крила літака) та країну реєстрації;

- власника повітряного судна.

Позивний ПС складається 3 літер та цифр довжиною до 8 символів. Для нерейсових літаків немає загальних правил встановлення позивного. Досить часто у якості позивного такі літаки використовують реєстраційний номер ПС. Для рейсових літаків позивний однозначно визначає рейс, за яким здійснюється політ.

Методи об'єднання інформачії від радіолокаційних засобів та приймачів $A D S-B$. При використанні даних ADS-B в радіотехнічних підрозділах, вони, на відміну від підрозділів УПР, носять додатковий характер. Підтверджувати присутність ПС, що виявлене за даними ADS-B, потрібно тільки у випадку його виявлення якимось радіолокаційним засобом.

Ототожнення виконується при попаданні відмітки ПС від ADS-B та РЛС в один багатомірний строб. Вимірами стробу $є$ різниці по простору, швидкості, курсу та висоті (останнє тільки для трикоординатних РЛС).

При отриманні радіолокаційних даних від трасової РЛС обов'язковим $є$ співпадання коду SQUAWK. При виконанні умов ототожнення, дані від ADS-B (тип ПС, реєстраційний номер, власник ПС, позивний ПС, в деяких випадках номер рейсу та аеропорти вильоту та прильоту) автоматично (автоматизовано) прив'язуються до цілі, яка 
супроводжується РЛС. При супроводженні такої цілі координатні параметри доцільно брати від ADSВ (положення цілі, значення висоти, швидкості та курсу) які значно точніше за значення цих параметрів від РЛС. У випадку виходу цілі з зони дії приймача ADS-B, здійснюється автоматичний перехід на супроводження за даними РЛС зі збереженням некоординатних даних ADS-B.

Особливості та обмеження на використання інформації ADS-B. Наявність даних ADS-B дозволяе отримувати додаткову інформацію про повітряні цілі та підвищити точність їх супроводу. Значною перевагою є те, що ці дані можна отримувати для ПС, що не входять у повітряний простір України i відповідно про які нема відомостей у органах УПР України. Тобто з'являється можливість отримувати дані про ПС, що здійснюють польоти вздовж кордону України не перетинаючи його.

Вочевидь, що найбільш “цікаві” для пунктів управління авіацією ПС ЗСУ цілі не будуть працювати в ADS-B. Але при наявності такої інформації від інших ПС (які складають 99\% користувачів повітряного простору) виділення таких “цікавих” цілей на фоні інших значно спрощується.

Дані ADS-B можна використовувати в якості еталонних вимірів при проведенні іспитів радіолокаційних засобів зокрема при оцінці точності виміру координат, а також для перевірки та корегування їх юстировки.

Отримання даних ADS-B безпосередньо на зенітних ракетних комплексах, особливо при їх автономній роботі, дозволяє суттєво підвищити безпеку виконання бойових стрільб.

Але до даних, що надходять від приймачів ADS-B, треба відноситися 3 певною мірою довіри тому що технічно противник може свідомо спотворити ці дані. Хоча спотворення цих даних i заборонено, але при організації провокаційних дій противник може свідомо йти на такі порушення. Наприклад, можна виготовити радіопередавальний пристрій, що буде випромінювати сигнали від реально не існуючих цілей. Наявність таких “віртуальних" цілей можна виявити шляхом порівняння даних ADS-B з даними, що отримуються від радіолокаційних засобів. Ще більш ефективним є застосування технології MLAT, яка дозволяє визначити координати розташування такого передавача. Що одним способом спотворення може бути підміна координат в повідомленнях ADS-B. Більш того, такі спотворення можуть надходити від законослухняних користувачів повітряного простору. Наприклад, якщо супутниковій навігаційній системі літака поставити відповідні завади. Виявлення таких спотворень здійснюється також порівнянням з радіолокаційними даними або застосування технології MLAT. Найбільш неприємним може бути підміна в повідомленнях адреси ICAO повітряного судна. Тобто, наприклад літак-розвідник “мімікрує” під реально існуючий пасажирський літак Boeing737, данні про який присутні в базі даних. Виявити таку підміну шляхом порівняння 3 радіолокаційними даними або використання технології MLAT не можливо. Рішення здачі по виявленню такої ситуації можна здійснити декількома шляхами. По-перше, від органів УПР потрібно постійно отримувати дані по запланованим перельотам i перевіряти цю інформацію 3 поточними даними про повітряну обстановку. На жаль, органи УПР можуть надати інформацію тільки про ПС які здійснюють або планують здійснювати політ тільки у межах повітряного простору України. По-друге, можливо ПС під якого здійснюється “мімікрія” само в даний час виконує політ. Тоді, в різних точках повітряного простору будуть спостерігатися два, або і більше ПС 3 однаковим номером ICAO. Наявність такої ситуації свідчить про факт підміни. По-третє. Законослухняне ПС використовує ADS-B на протязі всього польоту. Повітряне судно - порушник буде використовувати підміну тільки на деяких ділянках польоту. Таким чином законослухняне ПС що здійснює переліт буде виявлятися на максимальній дальності виявлення приймача для висоти польоту ПС. Відповідно, якщо в системі ADS-В виявляється ПС всередині зони дії приймача на великій висоті польоту (тобто ПС не здійснює зліт з аеродрому), то це на пряму може свідчити про можливе спотворення даних ADS-B.

\section{Висновки}

Основними перевагами запропонованого методу обєднання інформації від радіолокаційних засобів та приймачів ADS-B при веденні РЛК повітряної обстановки з використанням технології MLAT $€$ :

- скорочення часу на отримання інформації про повітряні цілі та підвищити точність їх супроводу;

- інформацію можна отримувати для ПС, що не входять у повітряний простір України і відповідно про які нема відомостей у органах УПР України. Тобто з'являється можливість отримувати дані про ПС, що здійснюють польоти вздовж кордону України не перетинаючи його;

- можливість використання в якості контрольних об'єктів випадкових ПО, що пролітають в зоні відповідальності пунктів управління авіацією ПС ЗСУ та оснащені транспондерами ADS-B.

Використання приймачів системи ADS-B на позиціях пунктів управління авіацією ПС ЗСУ дасть черговій бойовій обслузі змогу зменшити допустиме відхилення виміряних часових затримок. Це зумовлено насамперед тим, що точність приймачів 
ADS-B визначається точністю визначення координат в системі GPS.

Актуальність застосування методу обєднання інформації висока [11]. Безпілотні літаки, дрони, в найближчому майбутньому будуть базуватися на використанні супутникової навігації і будуть використовувати технологію ADS-B, або альтернативні системи, що сутєво підвищить ефективність роботи чергової бойової обслуги пунктів управління авіацією ПС ЗСУ.

\section{Список літератури}

1. Авиационная электросвязь. T IV. Системы обзорной радиолокации и предупреждения столкновений. Международная организация гражданской авиации [Електронний ресурс]. - ИКАО, 2007. - 304 c. - Available at: http://uaecis.com/files/an10_v4.pdf.

2. Технические положения, касающиеся услуг режима $\mathrm{S}$ и расширенного сквиттера [Електронний ресурс]. - ИКАО, 2012. - 352 c. - Режим доступу: https://www.twirpx.com/file/1206815/.

3. SUR.ET1.ST01.1000-STD-01-01 Eurocontrol Standard Document for Radar Surveillance in En-route Airspace and Major Terminal Areas.- Ed. 1.0. - Eurocontrol, 1997. - 124 p.

4. ICAO. Afi planning and implementation regional group seventeenth meeting (APIRG/17). Burkina Faso, Air Navigation Planning and Implementation Issues. Communications, Navigation and Surveillance (CNS). - 2010. - Режим доступу: http://www.icao.int/.

5. Використання інформації ADS-B в інтересах підвищення якості ведення радіолокаційної розвідки повітряного простору // С.П. Лещенко, О.М. Колесник, С.А. Грицаєнко, С.І. Бурковський // Наука і техніка Повітряних Сил Збройних Сил України. - 2017. - № 3(28). - С. 69-75. https://doi.org/10.30748/nitps.2017.28.09.

6. Маляренко А.С. Системы вторичной радиолокации для управления воздушным движением и государственного опознавания. Справочник / А.С. Маляренко. - Х.: ХУВС, 2007. - 78 с.

7. Коваленко А.А. Методи синтезу інформаційної та технічної структур системи управління об'єктом критичного застосування / А.А. Коваленко, Г.А. Кучук // Сучасні інформаційні системи. - 2018. - № 1(2). - С. $22-27$.

8. Вибір способу формування цифрового коду азимутального положення антени в оглядових РЛС “старого” парку / О.А. Малишев, М. Р. Арасланов, О.М. Піскун, С.С. Чекіров // Системи озброєння і військова техніка. - 2018. - № 1(53). C. $175-182$.

9. Ширман Я.Д. Теоретические основы радиолокации / Я.Д. Ширман. - М.: Сов. радио, 1970. - 560 с.

10. Федоров А.В. Метод юстування радіолокаційної станції радіотехнічних військ $з$ використанням технології автоматичного залежного спостереження / А.В. Федоров, Г.В. Худов, О.В. Сова // Системи управління, навігації та зв'язку. - 2019. - № 2(54). - С. 155-158.

11. Сухов В.В. Внедрение технологии автоматического зависимого наблюдения в системы контроля воздушного пространства / В.В. Сухов // Новые технологии. - 2012. - № 1. - С. 67-70.

\section{Відомості про авторів:}

\section{Кадук Сергій Олександрович}

викладач

Харківського національного університету

Повітряних Сил ім. І. Кожедуба,

Харків, Україна

https://orcid.org/0000-0002-2932-7416

\section{Сторожук Андрій Сергійович}

курсант

Харківського національного університету

Повітряних Сил ім. І. Кожедуба,

Харків, Україна

https://orcid.org/0000-0002-3188-37020

\section{Стрельчик Євгеній Юрійович}

курсант

Харківського національного

університету Повітряних Сил ім. І. Кожедуба,

Харків, Україна

https://orcid.org/0000-0001-5889-96270

\section{Information about the authors:}

\section{Sergiy Kaduk}

Instructor

of Ivan Kozhedub Kharkiv

National Air Force University,

Kharkiv, Ukraine

https://orcid.org/0000-0002-2932-7416

\author{
Andriy Storozhuk \\ Cadet \\ of Ivan Kozhedub Kharkiv \\ National Air Force University, \\ Kharkiv, Ukraine \\ https://orcid.org/0000-0002-3188-37020
}

\section{Evgeniy Strelchik \\ Cadet}

of Ivan Kozhedub Kharkiv

National Air Force University,

Kharkiv, Ukraine

https://orcid.org/0000-0001-5889-96270 
Сікорський Роман Андрійович

курсант

Харківського національного

університету Повітряних Сил ім. І. Кожедуба, Харків, Україна

https://orcid.org/0000-0002-2685-0113

\section{Roman Sikorskyi}

Cadet

of Ivan Kozhedub Kharkiv

National Air Force University,

Kharkiv, Ukraine

https://orcid.org/0000-0002-2685-0113

\title{
ИСПОЛЬЗОВАНИЕ ИНФОРМАЦИИ РАДИОЛОКАЦИОННОЙ РАЗВЕДКИ АDS-В ПРИ СОЗДАНИИ ЕДИНОГО ИНФОРМАЦИОННОГО ПРОСТРАНСТВА ВОЗДУШНЫХ СИЛ ВООРУЖЕННЫХ СИЛ УКРАИНЫ
}

\author{
С.А. Кадук, А.С. Сторожук, Е.Ю. Стрельчик, Р.А. Сикорский
}

Современные информационные технологии позволяют создавать информационное пространство путем объединения различной информации от разнородных источников. В статье рассмотрены способы, реализация которых может обеспечить снижение затрат времени, достигается в интегрированных системах по контролю воздушного пространства за счёт совместного использования ресурсов разных ведомств. Проведен анализ последних исследований и публикаций, руководящих документов Министерства обороны и требования Евроконтроля к системам радиолокационного наблюдения и средств радиолокации. Описаны распознавание ситуаций и ситуации, которые возникают в воздушном пространстве. Определены методы обобщения информации от радиолокационных средств и приёмников ADS-B. Рассмотрены методы объединения информации от радиолокационных средств и приёмников ADSB, основные преимущества предложенного метода, а также актуальность применения его в будущем. Показано, что за счёт ADS-B данных можно получить дополнительную информачию для предупреждения нарушений в воздушном пространстве Украинь.

Ключевые слова: радиолокационный контроль, нарушения воздушного пространства, оценка воздушной обстановки, MLAT, ADS-B.

\section{USE OF ADS-B RADAR SECURITY INFORMATION IN CREATION OF A UNIFIED INFORMATION SPACE OF THE AIR FORCES OF THE ARMED FORCES OF UKRAINE}

\author{
S. Kaduk, A. Storozhuk, E. Strelchik, R. Sikorskyi
}

Modern information technologies make it possible to create an information space by combining various information from different sources. The article discusses the ways, the implementation of which can reduce the time spent, it is achieved in integrated systems for airspace control due to the joint use of resources of different departments. An analysis of recent studies and publications, guidelines of the ministry of defense and eurocontrol requirements for radar surveillance systems and radar equipment was carried out. Recognition of situations and situations that arise in airspace are described. Methods for generalizing information from radar facilities and ADS-B receivers have been determined. Methods for combining information from radar facilities and ads- $b$ receivers, the main advantages of the proposed method, as well as the relevance of its application in the future are considered. It is shown that due to ads-b data, additional information can be obtained to prevent violations in the airspace of Ukraine.

Keywords: radar control, air intrusion, air situation assessment, MLAT, ADS-B. 